\title{
Airway irritation among indoor swimming pool personnel: trichloramine exposure, exhaled NO and protein profiling of nasal lavage fluids
}

\author{
Louise Fornander, Bijar Ghafouri, Mats Lindahl and Pål Graff
}

\section{Linköping University Post Print}

\section{Tweet}

N.B.: When citing this work, cite the original article.

The original publication is available at www.springerlink.com:

Louise Fornander, Bijar Ghafouri, Mats Lindahl and Pål Graff, Airway irritation among indoor swimming pool personnel: trichloramine exposure, exhaled NO and protein profiling of nasal lavage fluids, 2013, International Archives of Occupational and Environmental Health, (86), 5, 571-580.

http://dx.doi.org/10.1007/s00420-012-0790-4

Copyright: Springer Verlag (Germany)

http://www.springerlink.com/?MUD=MP

Postprint available at: Linköping University Electronic Press http://urn.kb.se/resolve?urn=urn:nbn:se:liu:diva- 86713 
Airway irritation among indoor swimming pool personnel; trichloramine exposure, exhaled NO and protein profiling of nasal lavage fluids

Louise Fornander ${ }^{1}$, Bijar Ghafouri ${ }^{1,2,3,4}$, Mats Lindahl ${ }^{1}$, Pål Graff ${ }^{1,3}$

${ }^{1}$ Occupational and Environmental Medicine, Department of Clinical and Experimental Medicine, Faculty of Health Sciences, Linköping University, Linköping, Sweden

${ }^{2}$ Rehabilitation Medicine, Department of Medicine and Health Sciences, Faculty of Health Sciences, Linköping University

${ }^{3}$ Centre of Occupational and Environmental Medicine, County Council of Östergötland, Linköping, Sweden

${ }^{4}$ Pain and Rehabilitation Centre, County Council of Östergötland, Linköping, Sweden

Corresponding author: Pål Graff

Postal address: Occupational and Environmental Medicine, County Council of Östergötland, SE-58185

Linköping, Sweden

E-mail: pal.graff@lio.se

Telephone number: +46-10-1034412

Telefax number: +46-13-145831 


\section{ABSTRACT}

Purpose Occurrence of airway irritation among indoor swimming pool personnel was investigated. The aim was to assess trichloramine exposure levels and exhaled nitric oxide in relation to the prevalence of airway symptoms in swimming pool facilities and to determine protein effects in the upper respiratory tract.

Methods The presence of airway symptoms related to work were examined in 146 individuals working at 46 indoor swimming pool facilities. Levels of trichloramine, as well as exhaled nitric oxide, were measured in five facilities with high prevalence of airway irritation and four facilities with no airway irritation among the personnel. Nasal lavage fluid was collected and protein profiles were determined by a proteomic approach.

Results $17 \%$ of the swimming pool personnel reported airway symptoms related to work. The levels of trichloramine in the swimming pool facilities ranged from $0.04-0.36 \mathrm{mg} / \mathrm{m}^{3}$. There were no covariance between trichloramine levels, exhaled nitric oxide and prevalence of airway symptoms. Protein profiling of the nasal lavage fluid showed that, alpha-1-antitrypsin and lactoferrin, were significantly higher, and S100-A8 was significantly lower in swimming pool personnel.

Conclusions This study confirms the occurrence of airway irritation among indoor swimming pool personnel. Our results indicate altered levels of innate immunity proteins in the upper airways that may pose as potential biomarkers. However, swimming pool facilities with high prevalence of airway irritation could not be explained by higher trichloramine exposure levels. Further studies are needed to clarify the environmental factors in indoor swimming pools that cause airway problems and affect the immune system.

Key terms: innate immunity, occupational medicine, proteomics, upper respiratory tract. 


\section{INTRODUCTION}

Swimming is considered to have positive health effects and indoor swimming pools are popular recreation resorts worldwide. However, people frequently being in the environment often experience airway, eye or dermatological problems (WHO 2006; Nemery et al. 2002). Several studies have showed that personnel, like lifeguards and pool attendants, suffer from nasal and throat symptoms, often together with eye irritation (Massin et al. 1998; Demange et al. 2009; Dang et al. 2010; Fantuzzi et al. 2010; Jacobs et al. 2007). There are also studies indicating that children frequently visiting indoor swimming pools have an increased risk to develop asthma and allergy (Bernard et al. 2005; Bernard et al. 2006), although the opposite has also been found (Font-Ribera et al. 2011). In light of these possible public health hazards associated to swimming pools, the World Health Organization (WHO) has provided guidelines for management, exposure monitoring and risk evaluation (WHO 2006).

To avoid spread of infectious diseases among bathers, the water is disinfected and the most widespread method is by chlorination. However, when chlorine comes in contact with nitrogen containing substances in the water, such as urine, sweat and skin cells, irritating volatile by-products are formed, i.e. different forms of chloramine gases. One of these is trichloramine, which is easily evaporated and then enriched above the surface of the water (Weaver et al. 2009; Schmalz et al. 2011). It is also predicted that crowded modern adventure bath with waterfalls, water slides and bubble pools could generate higher trichloramine levels in the air (Hery et al. 1995; Richardson et al. 2010). There are still gaps in the knowledge about the health effects of trichloramine, but many studies suggests it as the most important cause for airway symptoms among employees and visitors (Massin et al. 1998; Jacobs et al. 2007; Levesque et al. 2006). In addition, trichloramine induced occupational asthma has been reported (Thickett et al. 2002).

Some efforts have been made to establish biomarkers for airway effects after chlorinated swimming pool environment exposure. One candidate is fractional exhaled nitric oxide (NO), a marker of 
inflammation, which has been found to be associated to pool attendance in children (Bernard et al. 2005) and airway responsiveness in lifeguards (Demange et al. 2009). In addition, a few protein biomarkers have been assessed in swimmers. Thus, increased serum levels of surfactant proteins (SPA and SP-B) have been found after swimming in chlorinated pools (Carbonnelle et al. 2002) and associated to pool attendance in children (Bernard et al. 2005). Furthermore, increased serum levels of Clara cell secretory protein 16 (CC16) have been suggested as a short-term marker after swimming in chlorinated pools (Font-Ribera et al. 2010), although other results indicates CC16 being a marker of exercise rather than exposure to chlorinated irritants (Carbonnelle et al. 2002). Both SP-A/SP-B and CC16 are typical airway proteins and increased levels in serum are believed to reflect increased epithelial permeability, e.g. caused by exposure to irritants. In contrast to these studies, no similar efforts have been made to investigate protein changes in airway samples in connection to irritant exposure at indoor swimming pool facilities. In this respect, nasal lavage is a sampling technique that can be used to measure inflammatory states in the upper respiratory tract. Nasal lavage fluid (NLF) is especially useful in occupational exposure studies, since it is easily collected and non-invasive for the subjects participating (Norback and Wieslander 2002). We have previously analyzed NLF to detect protein changes in smokers (Ghafouri et al. 2002) and to identify protein biomarkers after exposure to irritating epoxy chemicals (Lindahl et al. 2004).

In this study we investigated the occurrence of airway symptoms among personnel working at 46 Swedish indoor swimming pool facilities. The exposure to trichloramine and exhaled NO were then assessed in employees at 5 swimming pool facilities with high prevalence of airway irritation and 4 facilities without cases of airway irritation. Finally, NLF were collected from a group of exposed subjects and analyzed with a proteomic approach to detect protein pattern changes that may pose new potential biomarkers. 


\section{SUBJECTS AND METHODS}

\section{Chemicals}

TEMED, $40 \%$ acrylamide solution, $2 \%$ bis-acrylamide solution, Tween 20 and ammonium persulfate were obtained from Bio-Rad Laboratories (Hercules, CA, USA). lodocetamide, DTT, sodium dodecyl sulfate (SDS), CHAPS, 2,5-dihydroxybenzoic acid, acetonitrile and trifluoroacetic acid were all purchased from Sigma-Aldrich (St. Louis, MI, USA). IPG buffer pH 3-10 NL, IPGs NL 3-10, and dry strip cover fluid were acquired from GE Healthcare and porcine trypsin was from Promega (Madison, WI, USA). The calibration mixture for peptide mass fingerprinting; des-Arg1-bradykinin, angiotensin I, Glu1-fibrinopeptide B, neurotensin, adrenocorticotropic hormone (ACTH, clip 1-17), ACTH (clip 1839), ACTH (clip7-38) with masses: 904.4681, 1296.6853, 1570.6774, 1672.9175, 2093.0867, 2465.1989, 3657.9294, respectively, were purchased from Applied Biosystems (Foster City, CA, USA).

\section{Study design}

A cross-sectional descriptive study of indoor swimming pool facilities in the south-east healthcare region of Sweden was performed. The study was approved by the local ethical board (Dnr: M64-07) and written consent was obtained from all participants. Originally, 46 public indoor swimming pool facilities were visited. The study comprised different types of facilities such as adventure baths and rehabilitation baths as well as regular swimming pools. The employees $(n=146,58$ men and 88 women) were interviewed regarding work environment and health status, including airway symptoms related to work. All subjects included in the study were full-time employees. From the interview result, 9 facilities were selected, based on highest ( 5 facilities) and lowest ( 4 facilities) prevalence of self-stated airway symptoms, for further investigations. Air levels of trichloramine were measured in the facilities and NO assessed in exhaled breath from all full-time employees $(n=39)$. These individuals also answered a questionnaire regarding; duration of employment at 
indoor swimming pool facilities, last work period in days, specific job assignment at the work place, prevalence of airway symptoms related to work and, if applicable, description of symptoms etc. Three facilities were then selected for more detailed studies of the employees regarding trichloramine exposure levels and upper airway protein composition. These facilities were chosen based on the presence of personnel with airway symptoms and being facilities with different type of characteristics. Facility I (about 700 visitors/day) was an adventure bath with a total water surface area of $700 \mathrm{~m}^{2}$ consisting of one exercise pool (separate ventilating system), one bubble pool and an adventure pool with waves and a water slide. Facility II (about 300 visitors/day) contained an exercise pool and a shallow pool with a total area of $700 \mathrm{~m}^{2}$ and facility III (about 300 visitors/day) contained one exercise pool and one bubble pool with a total water surface area of $400 \mathrm{~m}^{2}$. To look for airway biomarkers NLF was collected from the personnel, five with reported airway symptoms (three females and two males, 28-56 years, median 41 year) and five without (two females and three males, 26-51 years, median 40 years). Exhaled NO was once again determined together with a supplementary questionnaire regarding health status. Inclusion criterion was working in a swimming pool facility with exposure to the pool environment. Exclusion criteria were current smoker and diagnosed asthma before beginning of work in swimming pool and atopy. None of the individuals subjected to NLF had developed asthma during their employment. In addition, five healthy nonsmoking controls (three females and two males, 25-50 years, median 35 years), not working at an indoor swimming pool facility, were included and examined in the same way. Two subjects were excluded from the analyses (one control and one of the swimming pool personnel) as they suffered from common cold at the time of NO determination and nasal lavage.

\section{Trichloramine measurement}

Trichloramine was measured in the facilities using sodium carbonate and arsenic trioxide impregnated filters coupled to AirCheck 2000 air sampling pump (SKC Inc., PA, USA) with a flow rate 
of $1 \mathrm{l} / \mathrm{min}$ (Hery et al. 1998). The samples were analyzed by ion specific electrode at the unit of Occupational and environmental medicine, Umeå University, Sweden. A Teflon filter was mounted in front of the impregnated filter that was coupled to the pump to avoid contamination from water droplets and mist during analysis. Measurements were performed for three hours at three different locations in each building and $1.3 \mathrm{~m}$ above floor level.

\section{Sample collection and preparations}

Samples were taken at site during winter at times with high visitor load. NLF was collected by introducing $15 \mathrm{ml}$ of $0.9 \%$ saline solution to the nasal cavity by a catheter and maintained there for 5 minutes before recovered. Mucous and cells were immediately removed by centrifugation (700 rcf) and samples were then kept on ice during transport to lab $(4 \mathrm{~h})$ where they were divided in aliquots

and stored in $-70^{\circ} \mathrm{C}$. Protein concentrations were determined according to Bradford (Bradford 1976). Exhaled NO was measured with NIOX Mino (Aerocrine, Solna, Sweden). The test was performed according to the manufacturer's instruction at a flow rate of $50 \mathrm{ml} / \mathrm{s}$. To prevent contamination of the sample with nasal air subjects exhaled against a positive counter pressure of $1013 \mathrm{hPa}$ and through a filter to avoid mucous to enter the measurement device. A reference value between 5-25 ppb was considered normal (Taylor et al. 2006).

\section{Multiplex assay}

Cytokines was measured in NLF using a Luminex $100^{\mathrm{TM}}$ instrument (Luminex, TX, USA) and Star Station software (Applied Cytometry, UK). A human cytokine 10-plex antibody bead kit (Invitrogen, CA, USA) for assessment of granulocyte macrophage-colony stimulating factor, interferon- $\gamma$, interleukin (IL)-1 $\beta$, IL-2, IL-4, IL-5, IL-6, IL-8, IL-10 and tumor necrosis factor- $\alpha$ in plasma or tissue 
culture supernatants, was used. Cytokine content in the samples was analyzed according to manufacturer's instructions.

\section{Immunoblotting}

NLF proteins $(5 \mu \mathrm{g})$ were separated by one-dimensional SDS polyacrylamide gel electrophoresis (5-20 \%) on Mini-Protean II electrophoresis Cell (Bio-Rad Laboratories, CA, USA). The samples was first run on $100 \mathrm{~V}, 60 \mathrm{~mA}$ for one hour and then elevated to $200 \mathrm{~V}, 60 \mathrm{~mA}$ until finished and transferred to a PVDF membrane using Mini-Trans blot cell (Bio-Rad Laboratories, CA, USA). The membranes were blocked in $5 \%$ non-fat dried milk in tris-buffered saline, pursued by primary antibody; $0.1 \mu \mathrm{g} / \mathrm{ml}$, short palate lung and nasal epithelial clone 1 (SPLUNC1), goat anti-human polyclonal IgG or 0.1 $\mu \mathrm{g} / \mathrm{ml}$, uteroglobin (Clara cell protein), rat anti-human monoclonal IgG (R\&D Systems, MN, USA), in 2 $\%$ non-fat dry milk in tris-buffered saline with Tween20. After incubation with HRP conjugated secondary antibodies (sheep anti-goat IgG antibody, Sigma, MI, USA or rabbit anti-rat IgG antibody, Abcam, United Kingdom) SPLUNC1 or Clara cell protein were detected by chemiluminescence and visualized on AGFA X-ray film.

\section{Two dimensional gel electrophoresis}

2-DE was performed as described in detail earlier (Ghafouri et al. 2006) on a horizontal 2-DE setup (IPGphor and Multiphor, GE Healthcare). In short, samples were desalted, lyophilized and resolved in 2-DE urea sample solution according to Görg (Gorg et al. 2000) and stored in -70 until use. Samples containing $50 \mu \mathrm{g}$ proteins from each subject were applied by in-gel rehydration for $12 \mathrm{~h}$ using low voltage $(30 \mathrm{~V})$ in $\mathrm{pH}$ 3-10 non-linear immobiline $\mathrm{pH}$ gradient gels (GE Healthcare, UK). The proteins were additionally focused to $38000 \mathrm{VHrs}$ at a maximum voltage of $8000 \mathrm{~V}$. After the first dimension, the gels were either used immediately or stored at $-70^{\circ} \mathrm{C}$. The second dimension was performed in 
gradient home cast gels on GelBond PAG film (0.5*180*245 mm, T: $11-18 \%$, C: $1.5 \%$, 33-0 \%

glycerol) running at $30 \mathrm{~mA}$ for about $20 \mathrm{~h}$. The gels were then silver stained according to Shevchenko (Shevchenko et al. 1996).

\section{Image analysis}

To visualize both X-ray films and 2DE-gels a cooled CCD (Charged-Coupled Device) camera digitizing at 1340x1040 pixels resolution (Fluor-S Multi-Imager, Bio-Rad Laboratories, CA, USA) was used. X-ray films from immunoblotting were further analyzed by Quantity One Version 4.6.9 and grayscale images from 2-DE gels were processed in PDQuest Version 8.0.1 (Bio-Rad Laboratories, CA, USA). The proteins were quantified according to optical densities, presented as percentage of total density in gel image.

\section{Identification of proteins with mass spectrometry}

Proteins spots were excised out of the gel, destained with $30 \mathrm{mM}$ potassium ferricyanide $/ 50 \mathrm{mM}$ sodium thiosulfate, according to Gharahdaghi et al (Gharahdaghi et al. 1999), followed first by incubation with $200 \mathrm{mM}$ ammonium bicarbonate and then with $100 \%$ acetonitrile to dehydrate the gel. Trypsin (10 mg/ml Sequencing Grade Modified, Promega, WI, USA) was added to the samples, incubated over night in $37^{\circ} \mathrm{C}$ and then dried in speed-vac. The peptides were reconstituted in $0.1 \%$ trifluoroacetic acid and mixed 1:1 with matrix (2,5-dihydroxybenzoic acid, $0.02 \mathrm{mg} / \mathrm{ml}$ ) as described previously (Ghafouri et al. 2007). The sample was applied onto the target plate (V700666 REV.C, Applied Biosystems) and the peptide masses were acquired using a matrix-assisted laser desorption ionization-time of flight mass spectrometry (MALDI-TOF MS, Voyager-DE PRO, Applied Biosystems, Foster City, CA, USA) using a $337 \mathrm{~nm} \mathrm{~N}$ laser, delayed extraction, positive ionization, operated in reflector mode and instrument settings as defined earlier (Ghafouri et al. 2007). Spectra in the mass 
range from 700 to $3600 \mathrm{~m} / \mathrm{z}$ were collected from 400 laser pulses/sample with close external mass calibration with a standard peptide mixture and internal calibration using known trypsin autolysis peaks ( $\mathrm{m} / \mathrm{z}$ 842.5100, 2211.1046). Acquired spectra were processed in Data Explorer ${ }^{\mathrm{TM}}$ Version 4.0 and the result were analyzed using Protein Prospector v.5.6.2, MS-Fit search in Swiss-Prot or NCBI databases. Restriction for all searches were placed on species (human), mass tolerance ( $\pm 50 \mathrm{ppm}$ ), cystein modification by carbamidomethylation and maximum missed cleavages by trypsin to one. The 50-100 most abundant peaks were used for database searches and identification of proteins with peptide mass fingerprinting.

\section{Statistical determinations}

As statistical method non-parametric test, Mann-Whitney U test, was used. A p-value $<0.05$ was considered statistical significant. Data are presented as mean \pm standard deviation if not stated otherwise. PASW Statistics 18 was used as statistical program. Correlation was calculated with nonparametric Spearman's rho. 


\section{RESULTS}

\section{Survey}

The survey of the personnel in 46 swimming pool facilities showed the occurrence of a wide range of symptoms related to work, mostly connected to the airways. Types of health problems found from the interviews and questionnaires were dry and mucus cough, hoarse throat, nasal obstruction, dryness and irritation of the eyes, rhinitis, chloracne, eczema, fatigue and headache. 25 of the 146 subjects (17\%) reported airway symptoms related to work. Of these, 5 were technicians and 20 bath attendants. There were no significant difference between men and women. The prevalence of airway symptoms was relative high, $31 \%$, among personnel employed $1-3$ years, declined to $6 \%$ in the group with 4-7 years employment and then increased to $22 \%$ in those that had worked more than seven years in swimming pool facilities. In a majority of the swimming pools $(32 / 46)$ the employees did not report any work-related airway symptoms. Instead, most of the cases of airway irritation were found in a relative small number of facilities. Thus, $64 \%$ of the subjects with airway symptoms $(16 / 25)$ worked at 6 of the 46 swimming pools. Five of these facilities with high prevalence of airway irritation (13 of 20 employees) and 4 facilities without any reported airway symptoms among the personnel (0 of 19 employees) were selected for trichloramine and NO measurements. The questionnaire of these 39 employees confirmed the results of the initial interviews.

\section{Trichloramine levels}

Measured trichloramine in the 9 facilities were on average $0.20 \mathrm{mg} / \mathrm{m}^{3}$ and ranged from 0.04 to 0.36 $\mathrm{mg} / \mathrm{m}^{3}$ (table 1). The mean levels were slightly higher in adventure baths $\left(0.23 \mathrm{mg} / \mathrm{m}^{3}, \mathrm{n}=3\right)$ compared with regular swimming pool facilities $\left(0.19 \mathrm{mg} / \mathrm{m}^{3}, \mathrm{n}=6\right)$. No correlation was found between trichloramine levels and the prevalence of airway symptoms. The mean trichloramine level were $0.16 \mathrm{mg} / \mathrm{m}^{3}\left(\mathrm{n}=5\right.$, range $\left.0.04-0.23 \mathrm{mg} / \mathrm{m}^{3}\right)$ in the facilities with relative high prevalence of 
airway symptoms compared to $0.26 \mathrm{mg} / \mathrm{m}^{3}\left(\mathrm{n}=4\right.$, range $\left.0.17-0.36 \mathrm{mg} / \mathrm{m}^{3}\right)$ in facilities without airway symptoms among the personnel. Additional measurements made in three of these facilities in connection with the collection of nasal lavages showed similar levels as the first measurements.

NO

Exhaled NO in the 39 subjects working at 9 facilities was $15+/-13 \mathrm{ppb}$. No covariance between NO and the prevalence of airway symptoms or type of facility was found (table 1). Analogously, NO in subjects with airway irritation was not significant different from individuals without symptoms; 16 +/- 17 and $13+/-6 \mathrm{ppb}$, respectively. NO measured in the 13 subjects subjected to nasal lavage were $17+/-8 \mathrm{ppb}$ and no significant differences were found between personnel with airway symptoms, personnel without airway symptoms and controls.

\section{Nasal lavage fluid analyses}

NLF from 13 individuals; four controls, and nine subjects working at indoor swimming pools as described in table 2 , were analyzed. The protein concentration was $75 \pm 25 \mu \mathrm{g} / \mathrm{ml}$. Of the 10 cytokines measured all, except interleukin 8 , were below detection limit (3-15 pg/ml). The level of IL8 was $439 \pm 167 \mathrm{pg} / \mathrm{ml}$. In addition, the endotoxin binding protein SPLUNC1 and Clara cell secretory protein (CC16) were assessed by immunoblotting. The results showed no significant differences in protein concentration, IL-8, SPLUNC1 or CC16 between personnel and controls or between subjects with airway symptoms compared to subjects without airway symptoms.

Protein profiles of the NLF were determined with 2-DE. The analyses showed three proteins, identified by mass spectrometry, differently expressed in the swimming pool personnel compared to controls (figure 1). As shown in figure 2, alpha-1-antitrypsin and lactoferrin was significantly higher 
while protein S100-A8 (calgranulin A) was significantly lower in swimming pool personnel than controls. In exposed subjects vs. controls, the distribution was: $0.08 \%(0.05-0.22)$ vs. $0.03 \%(0.01-$ 0.08) for alpha-1-antitrypsin; $4.54 \%$ (3.39-6.16) vs. $3.08 \%$ (2.24-4.49) for lactoferrin; and $0.09 \%$ (0.01-0.21) vs. $0.20 \%(0.11-0.33)$ for $\mathrm{S} 100-\mathrm{A} 8$, respectively (median and range, $\mathrm{p}<0.05)$. In all three proteins the changes were most pronounced in the subjects with airway symptoms (figure 2). In accordance with the western blot analyses, neither SPLUNC1 nor CC16 were significantly different in the swimming pool personnel. However, as shown in figure 3, a negative correlation between exhaled NO and SPLUNC1 was found ( $\left.p=0.001, r^{2}-0.796\right)$. 


\section{DISCUSSION}

This study show that almost one fifth (17\%) of indoor swimming pool personnel has airway symptoms related to work. The subjects reported different symptoms of mucosal irritation such as cough, hoarse throat, nasal obstruction, rhinitis and dryness of the eyes that became worse during work periods but improved during spare time. Most of the affected subjects (20 out of 25 ) had worked more than 3 years in the profession. However, the prevalence of airway irritation were relatively high (31\%) among those that had worked 3 years or less, showing that there is a considerable risk of developing airway irritation also after relative short time of employment. Actually, the prevalence was lower (6\%) in the group with 4-7 years of employment and then increased to $22 \%$ in the group that worked more than 7 years. This might indicate that sensitive individuals leave the profession at an early stage, not an uncommon phenomenon (healthy worker effect) among workers exposed to airway irritants (Ernst et al. 1989; Li and Sung 1999).

Interestingly, most of the personnel with airway symptoms (64\%) work at 6 of the 46 indoor swimming pools included in the first part of the study, indicating some decisive environmental factors present in these facilities. The main cause of airway irritation related to swimming pools is believed to be exposure to trichloramine (Massin et al. 1998; Dang et al. 2010). It is also likely that the levels of trichloramine are related to factors such as number of visitors, ventilation, water temperature, the size of the pools and type of pools. These factors were therefore considered and trichloramine were measured in facilities with high prevalence of airway irritation and compared to the levels in facilities without airway irritation among the personnel. To ensure that the trichloramine levels in the buildings were representative for time points with potential high exposure, measurements were undertaken during hours with the highest load of visitors and at different sites around the pools. The results, however, did not show that facilities with high prevalence of airway irritation had higher levels of trichloramine than facilities with low prevalence of airway symptoms, nor could we find any connection between trichloramine levels/airway symptoms/exhaled NO and 
size/type of pools. It should be emphasized that we in this study compared trichloramine levels in the swimming pools containing most cases of airway irritation with facilities without reported airway problems. So, although we did not measure trichloramine levels in all of the 46 facilities from the health survey it is unlikely that such measurements would reveal any connection between trichloramine levels and airway irritation in this study. However, it is important to point out that most of the affected subjects had worked for many years and we cannot exclude the possibility that the exposure to trichloramine could have been greater in the past.

In general, the levels of trichloramine found in this study (about $0.2 \mathrm{mg} / \mathrm{m}^{3}$ in the 9 facilities) are relative low compared to several other studies, which have shown levels about $0.5 \mathrm{mg} / \mathrm{m}^{3}$ (Dang et al. 2010; Jacobs et al. 2007; Thickett et al. 2002). Almost all of the facilities in this study had trichloramine levels below the recommended WHO-threshold value of $0.3 \mathrm{mg} / \mathrm{m}^{3}$ (WHO 2006). Only in one facility the exposure level $\left(0.36 \mathrm{mg} / \mathrm{m}^{3}\right)$ was above the WHO guidelines. Notably, at this facility the personnel did not report any airway symptoms. Concerning type of swimming pool, adventure baths are believed to generate higher trichloramine levels (Bernard et al. 2006). In this study we found slightly higher levels in adventure baths compared to regular pools, but there was no significant difference. However, it should be noted that the two highest mean trichloramine levels were found in two adventure baths and that the peak values $\left(0,35-0,57 \mathrm{mg} / \mathrm{m}^{3}\right)$ were measured at the adventure parts in these facilities.

Exhaled NO is today frequently used to assess airway inflammation and has even become a tool for asthma diagnosis (Taylor et al. 2006). In a study of lifeguards working at indoor swimming pool facilities increased exhaled NO was found to be associated with airway hyperresponsiveness (Demange et al. 2009). Furthermore, in children, elevated exhaled NO, defined as $>30 \mathrm{ppb}$, has been found to be associated with chlorinated pool attendance (Bernard et al. 2005). In contrast, most individuals (35 of 39) in our study had NO levels within the normal range for healthy subjects (5-25 
$\mathrm{ppb}$ ) and we could not find any connection between exhaled NO and airway symptoms or type of swimming pool facility. One subject of 39 was asthmatic and had a NO level of $70 \mathrm{ppb}$.

The proteomic analyses revealed three significant changes in the protein distribution patterns of NLF from indoor swimming pool personnel; more of alpha-1-antitrypsin and lactoferrin and less of protein S100-A8, proteins that are all involved in innate immunity. Notably, these protein effects were most pronounced in the subjects with airway irritation. Alpha-1-antitrypsin is a protease inhibitor important for airway tissue protection by inhibition of elastase from neutrophils during infectious and inflammatory states. The protein is expressed as different isoforms depending on glycosylation and the presence of negatively charged sialyl groups (Packer et al. 1998). Interestingly, we found increased levels of the most acidic, i.e. most glycosylated, isoform. This is in agreement with previous studies showing specific up-regulation of this isoform in NLF from smokers (Ghafouri et al. 2002) and patients with allergic rhinitis (Ghafouri et al. 2006). Other studies has showed increased levels of alpha-1-antitrypsin in bronchoalveolar lavage fluid (BALF) in coal miners with pneumoconiosis (Vallyathan et al. 2000), as well as in people nonoccupationally exposed to asbestos (Archimandriti et al. 2009). Lactoferrin is a protein with diverse effects, but is mostly recognized as having antimicrobial properties. It works through two main functions; binding up free iron and thereby depriving the bacteria its nutrients or by causing lysis by attaching to surfaces of fungi, viruses, parasites and bacteria (Garcia-Montoya et al. 2011). Increased levels of lactoferrin has previously been found in BALF from asthmatics (van de Graaf et al. 1991). Finally, protein S100-A8 is an abundant protein in neutrophils and found in high levels as a heterodimer with S100-A9 (calprotectin) in extracellular fluids during inflammation. The protein has antimicrobial activity and S100-A8 is an endogenous ligand to Toll-like receptor 4 that enhance LPS-induced production of cytokines (Vogl et al. 2007). In contrast, anti-inflammatory roles of S100-A8, through e.g. radical scavenging and zinc-binding, have also been proposed (Goyette and Geczy 2010). 
The proteomic approach used is a non-biased study design that allows simultaneous assessment of hundreds of proteins in biological samples in the same analysis. This has proven useful for initial toxicological hypothesis generating studies in occupational medicine (Lindahl et al. 2004; Wetmore and Merrick 2004). However, it is important to point out that the proteins identified in this pilot study, of a small group of swimming pool personnel, must be considered possible candidate biomarkers that need more extended studies using immunological assays.

In addition to trichloramine, microbial growth in the damp pool environment with release of proinflammatory bacterial products such as endotoxins has been suggested as a cause of airway symptoms (Dang et al. 2010). We have previously identified a novel endotoxin-binding protein, SPLUNC1 (also known as BPI fold-containing family A member 1), in the upper airways as a possible biomarker for environmental-induced airway irritation (Ghafouri et al. 2002; Ghafouri et al. 2006; Ghafouri et al. 2004). In this study we found a negative correlation between SPLUNC1 in NLF and exhaled nitric oxide. Together with the altered levels of three proteins involved in innate immunity responses towards bacteria makes it possible to speculate that besides the chlorination of the pools also microbial growth may be a factor causing the airway symptoms of the swimming pool personnel. In summary, in this study we found that $17 \%$ of the indoor swimming pool personnel reported airway irritation related to work. Furthermore, altered distribution of three innate immunity proteins, protein S100-A8, lactoferrin and alpha-1-antitrypsin, were found in NLF from employees at the facilities. Although subjects with airway irritation were overrepresented in a few swimming pool facilities we did not find higher trichloramine levels at these facilities. This suggests that factors other than trichloramine might contribute to the experienced airway problems. Further studies are needed to clarify if exposure to trichloramines or microbial products, such as endotoxins, may be related to the effects and if the identified proteins may be used as biomarkers for airway irritation among indoor swimming pool personnel. 


\section{ACKNOWLEDGEMENTS}

We like to thank the Swedish Work Environment Authority for valuable help during the first interviewing part of the study and especially Kjell Hågestad for further help with trichloramine measurements. This study was supported by the Research Council of South East Sweden (FORSS9026).

\section{CONFLICT OF INTEREST}

The authors declare that they have no conflict of interest. 


\section{REFERENCES}

Archimandriti DT, Dalavanga YA, Cianti R, Bianchi L, Manda-Stachouli C, Armini A, Koukkou Al, Rottoli $\mathrm{P}$, Constantopoulos SH, Bini L (2009) Proteome analysis of bronchoalveolar lavage in individuals from metsovo, nonoccupationally exposed to asbestos. J Proteome Res 8 (2):860869. doi:10.1021/pr800370n

Bernard A, Carbonnelle S, de Burbure C, Michel O, Nickmilder M (2006) Chlorinated pool attendance, atopy, and the risk of asthma during childhood. Environ Health Perspect 114 (10):1567-1573

Bernard A, Carbonnelle S, Nickmilder M, de Burbure C (2005) Non-invasive biomarkers of pulmonary damage and inflammation: Application to children exposed to ozone and trichloramine. Toxicol Appl Pharmacol 206 (2):185-190. doi:S0041-008X(05)00081-5 [pii]

10.1016/j.taap.2004.10.022 [doi]

Bradford MM (1976) A rapid and sensitive method for the quantitation of microgram quantities of protein utilizing the principle of protein-dye binding. Anal Biochem 72:248-254

Carbonnelle S, Francaux M, Doyle I, Dumont X, de Burbure C, Morel G, Michel O, Bernard A (2002) Changes in serum pneumoproteins caused by short-term exposures to nitrogen trichloride in indoor chlorinated swimming pools. Biomarkers 7 (6):464-478. doi:10.1080/13547500210166612

Dang B, Chen L, Mueller C, Dunn KH, Almaguer D, Roberts JL, Otto CS (2010) Ocular and respiratory symptoms among lifeguards at a hotel indoor waterpark resort. J Occup Environ Med 52 (2):207-213. doi:10.1097/JOM.0b013e3181cf00d5

Demange V, Bohadana A, Massin N, Wild P (2009) Exhaled nitric oxide and airway hyperresponsiveness in workers: A preliminary study in lifeguards. BMC Pulm Med 9:53. doi:10.1186/1471-2466-9-53

Ernst P, Dales RE, Nunes F, Becklake MR (1989) Relation of airway responsiveness to duration of work in a dusty environment. Thorax 44 (2):116-120

Fantuzzi G, Righi E, Predieri G, Giacobazzi P, Mastroianni K, Aggazzotti G (2010) Prevalence of ocular, respiratory and cutaneous symptoms in indoor swimming pool workers and exposure to disinfection by-products (dbps). Int J Environ Res Public Health 7 (4):1379-1391. doi:10.3390/ijerph7041379

Font-Ribera L, Kogevinas M, Zock JP, Gomez FP, Barreiro E, Nieuwenhuijsen MJ, Fernandez P, Lourencetti C, Perez-Olabarria M, Bustamante M, Marcos R, Grimalt JO, Villanueva CM (2010) Short-term changes in respiratory biomarkers after swimming in a chlorinated pool. Environ Health Perspect 118 (11):1538-1544. doi:10.1289/ehp.1001961

Font-Ribera L, Villanueva CM, Nieuwenhuijsen MJ, Zock JP, Kogevinas M, Henderson J (2011) Swimming pool attendance, asthma, allergies, and lung function in the avon longitudinal study of parents and children cohort. Am J Respir Crit Care Med 183 (5):582-588. doi:10.1164/rccm.201005-07610C

Garcia-Montoya IA, Cendon TS, Arevalo-Gallegos S, Rascon-Cruz Q (2011) Lactoferrin a multiple bioactive protein: An overview. Biochim Biophys Acta. doi:10.1016/j.bbagen.2011.06.018

Ghafouri B, Irander K, Lindbom J, Tagesson C, Lindahl M (2006) Comparative proteomics of nasal fluid in seasonal allergic rhinitis. J Proteome Res 5 (2):330-338. doi:10.1021/pr050341h

Ghafouri B, Karlsson H, Mortstedt H, Lewander A, Tagesson C, Lindahl M (2007) 2,5-dihydroxybenzoic acid instead of alpha-cyano-4-hydroxycinnamic acid as matrix in matrix-assisted laser desorption/ionization time-of-flight mass spectrometry for analyses of in-gel digests of silverstained proteins. Anal Biochem 371 (1):121-123. doi:10.1016/j.ab.2007.07.002

Ghafouri B, Kihlstrom E, Tagesson C, Lindahl M (2004) Plunc in human nasal lavage fluid: Multiple isoforms that bind to lipopolysaccharide. Biochim Biophys Acta 1699 (1-2):57-63.

doi:10.1016/j.bbapap.2004.01.001 
Ghafouri B, Stahlbom B, Tagesson C, Lindahl M (2002) Newly identified proteins in human nasal lavage fluid from non-smokers and smokers using two-dimensional gel electrophoresis and peptide mass fingerprinting. Proteomics 2 (1):112-120

Gharahdaghi F, Weinberg CR, Meagher DA, Imai BS, Mische SM (1999) Mass spectrometric identification of proteins from silver-stained polyacrylamide gel: A method for the removal of silver ions to enhance sensitivity. Electrophoresis 20 (3):601-605

Gorg A, Obermaier C, Boguth G, Harder A, Scheibe B, Wildgruber R, Weiss W (2000) The current state of two-dimensional electrophoresis with immobilized ph gradients. Electrophoresis 21 (6):1037-1053

Goyette J, Geczy CL (2010) Inflammation-associated s100 proteins: New mechanisms that regulate function. Amino Acids. doi:10.1007/s00726-010-0528-0

Hery M, Gerber JM, Hecht G, Subra I, Possoz C, Aubert S, Dieudonne M, Andre JC (1998) Exposure to chloramines in a green salad processing plant. Ann Occup Hyg 42 (7):437-451

Hery M, Hecht G, Gerber JM, J.C. G, Hubert G, J. R (1995) Exposure to chloramines in the atmosphere of indoor swimming pools. Ann Occup Hyg 39 (4):427-439

Jacobs JH, Spaan S, van Rooy GB, Meliefste C, Zaat VA, Rooyackers JM, Heederik D (2007) Exposure to trichloramine and respiratory symptoms in indoor swimming pool workers. Eur Respir J 29 (4):690-698. doi:10.1183/09031936.00024706

Levesque B, Duchesne JF, Gingras S, Lavoie R, Prud'Homme D, Bernard E, Boulet LP, Ernst P (2006) The determinants of prevalence of health complaints among young competitive swimmers. Int Arch Occup Environ Health 80 (1):32-39. doi:10.1007/s00420-006-0100-0

Li CY, Sung FC (1999) A review of the healthy worker effect in occupational epidemiology. Occup Med (Lond) 49 (4):225-229

Lindahl M, Irander K, Tagesson C, Stahlbom B (2004) Nasal lavage fluid and proteomics as means to identify the effects of the irritating epoxy chemical dimethylbenzylamine. Biomarkers 9 (1):56-70. doi:10.1080/13547500410001662005

Massin N, Bohadana AB, Wild P, Hery M, Toamain JP, Hubert G (1998) Respiratory symptoms and bronchial responsiveness in lifeguards exposed to nitrogen trichloride in indoor swimming pools. Occup Environ Med 55 (4):258-263

Nemery B, Hoet PH, Nowak D (2002) Indoor swimming pools, water chlorination and respiratory health. Eur Respir J 19 (5):790-793

Norback D, Wieslander G (2002) Biomarkers and chemosensory irritations. Int Arch Occup Environ Health 75 (5):298-304. doi:10.1007/s00420-002-0314-8

Packer NH, Lawson MA, Jardine DR, Sanchez JC, Gooley AA (1998) Analyzing glycoproteins separated by two-dimensional gel electrophoresis. Electrophoresis 19 (6):981-988. doi:10.1002/elps.1150190613

Richardson SD, DeMarini DM, Kogevinas M, Fernandez P, Marco E, Lourencetti C, Balleste C, Heederik D, Meliefste K, McKague AB, Marcos R, Font-Ribera L, Grimalt JO, Villanueva CM (2010) What's in the pool? A comprehensive identification of disinfection by-products and assessment of mutagenicity of chlorinated and brominated swimming pool water. Environ Health Perspect 118 (11):1523-1530. doi:10.1289/ehp.1001965

Schmalz C, Frimmel FH, Zwiener C (2011) Trichloramine in swimming pools--formation and mass transfer. Water Res 45 (8):2681-2690. doi:10.1016/j.watres.2011.02.024

Shevchenko A, Wilm M, Vorm O, Mann M (1996) Mass spectrometric sequencing of proteins silverstained polyacrylamide gels. Anal Chem 68 (5):850-858

Taylor DR, Pijnenburg MW, Smith AD, De Jongste JC (2006) Exhaled nitric oxide measurements: Clinical application and interpretation. Thorax 61 (9):817-827. doi:10.1136/thx.2005.056093

Thickett KM, McCoach JS, Gerber JM, Sadhra S, Burge PS (2002) Occupational asthma caused by chloramines in indoor swimming-pool air. Eur Respir J 19 (5):827-832

Vallyathan V, Goins M, Lapp LN, Pack D, Leonard S, Shi X, Castranova V (2000) Changes in bronchoalveolar lavage indices associated with radiographic classification in coal miners. Am J Respir Crit Care Med 162 (3 Pt 1):958-965 
van de Graaf EA, Out TA, Kobesen A, Jansen HM (1991) Lactoferrin and secretory iga in the bronchoalveolar lavage fluid from patients with a stable asthma. Lung 169 (5):275-283

Weaver WA, Li J, Wen Y, Johnston J, Blatchley MR, Blatchley ER, 3rd (2009) Volatile disinfection byproduct analysis from chlorinated indoor swimming pools. Water Res 43 (13):3308-3318. doi:10.1016/j.watres.2009.04.035

Wetmore BA, Merrick BA (2004) Toxicoproteomics: Proteomics applied to toxicology and pathology. Toxicol Pathol 32 (6):619-642

WHO (2006) Guidelines for safe recreational water environments. World Health Organization 2: Swimming Pools and Similar Environments:Available: http://www.who.int/water sanitation health/bathing/srwe2full.pdf [accessed 31 August 2011]

VogI T, Tenbrock K, Ludwig S, Leukert N, Ehrhardt C, van Zoelen MA, Nacken W, Foell D, van der Poll T, Sorg C, Roth J (2007) Mrp8 and mrp14 are endogenous activators of toll-like receptor 4, promoting lethal, endotoxin-induced shock. Nat Med 13 (9):1042-1049. doi:10.1038/nm1638 


\section{LEGENDS TO FIGURES}

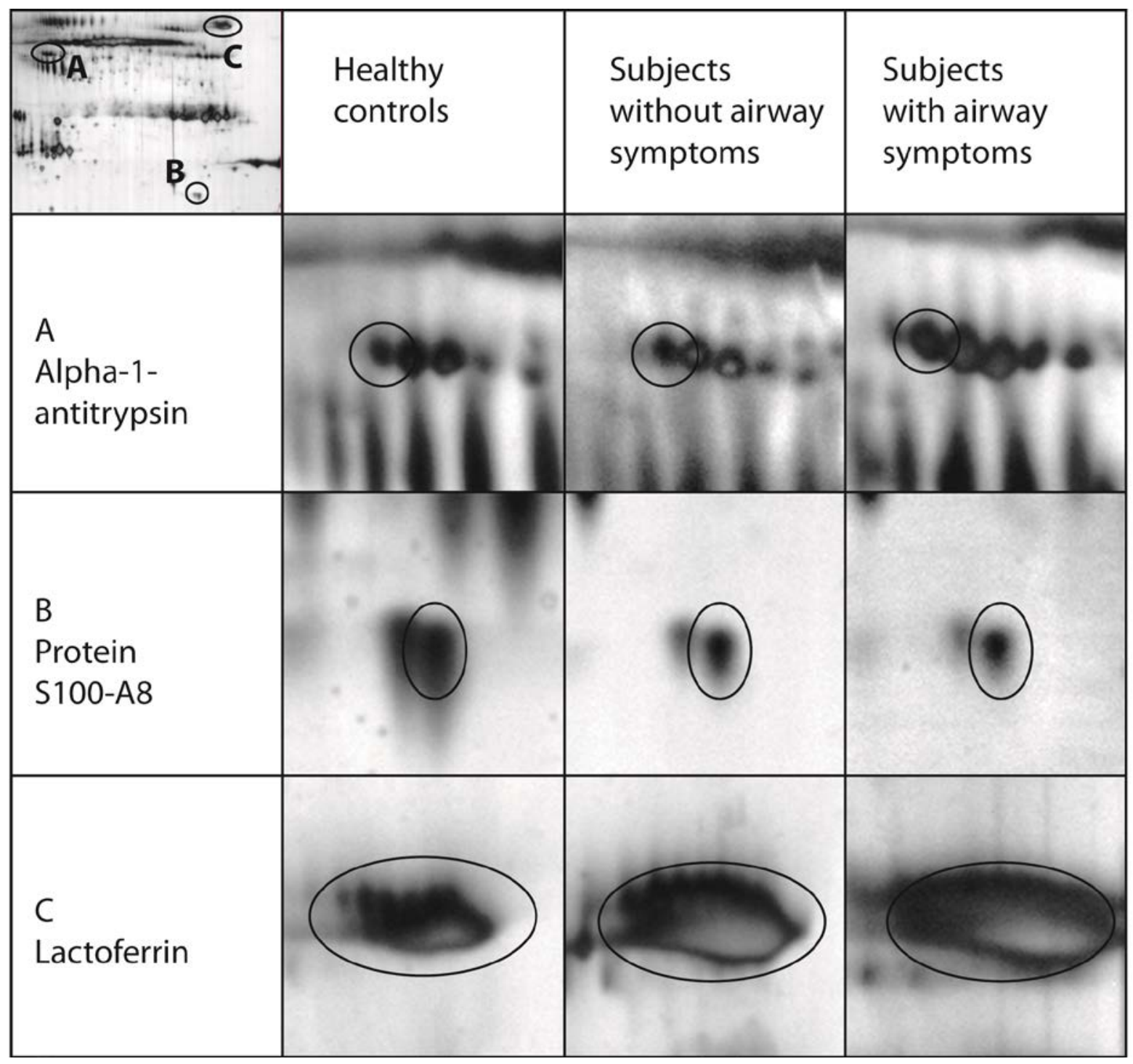

Figure 1. Protein changes in nasal lavage fluids from subjects working at indoor swimming pool

facilities. Proteins were separated with 2-DE and visualized with silver staining. An example of a whole 2-DE protein pattern is shown in the upper left corner. The proteins were separated according to size from top to bottom (250-5 kDa) and according to $\mathrm{pl}$ from left to right (3-10). 


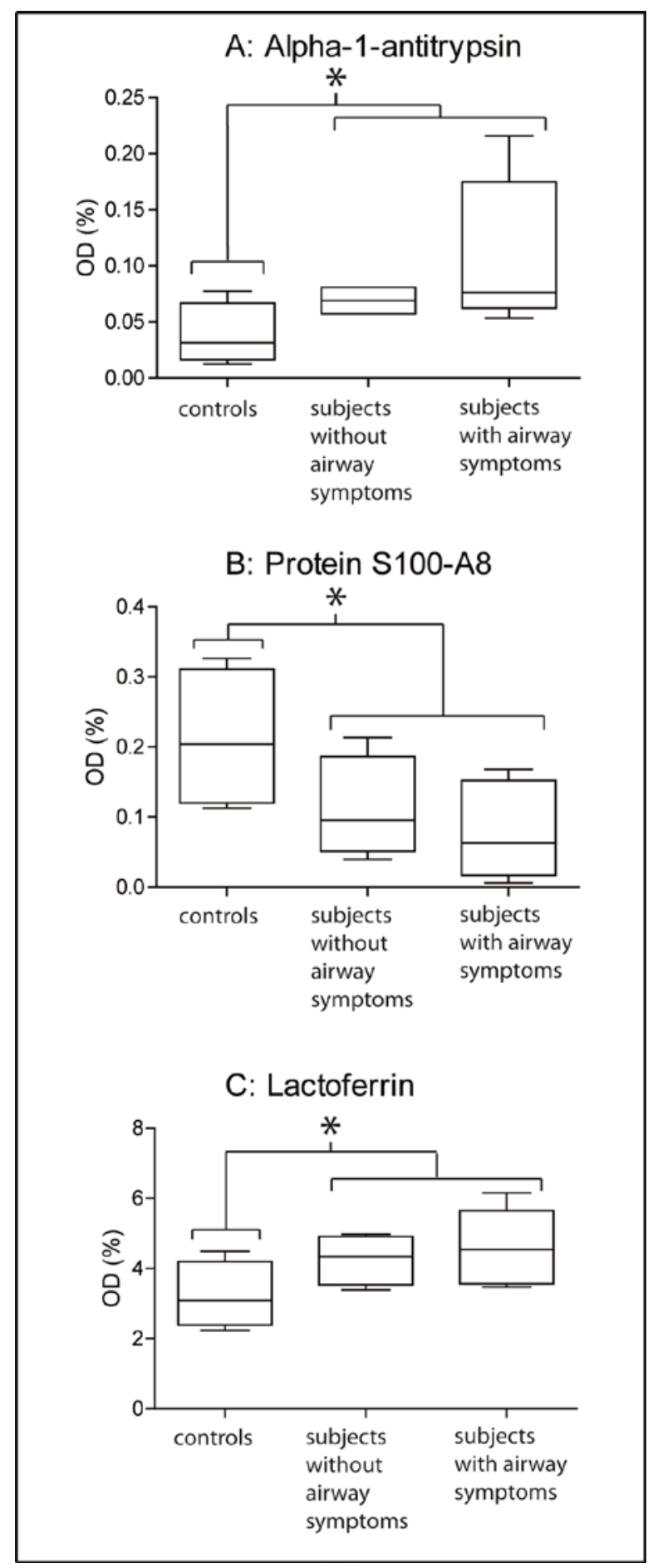

Figure 2. Distribution of alpha-1-antitrypsin (A), protein S100-A8 (B) and lactoferrin (C) in nasal lavage fluids from healthy controls and personnel working at indoor swimming pool facilities, with or without airway symptoms. The proteins were measured as optical density after 2-DE. The results are presented as $\%$ of total density in gel image, with median, interquartile range and max/min-values. $*=p<0.05$. 


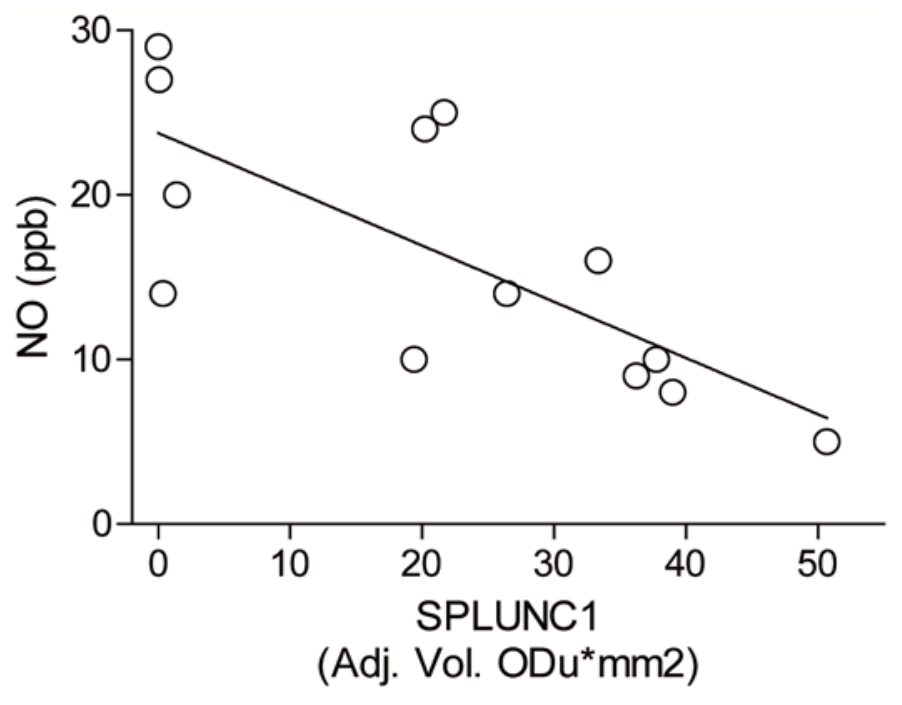

Figure 3. Correlation between exhaled NO and the amounts of SPLUNC1 in nasal lavage fluid $\left(p=0.001, R^{2}-0.796\right)$. 
Table 1. Trichloramine levels in nine indoor swimming pool facilities, and exhaled NO levels and prevalence of airway irritation among the personnel.

\begin{tabular}{lccc}
\hline Swimming pool & Trichloramine & Exhaled NO & Number of subjects \\
facility & mean $( \pm \mathrm{SD})$ & mean $( \pm \mathrm{SD})$ & (airway irritation/total) \\
& $\left(\mathrm{mg} / \mathrm{m}^{3}\right)$ & $(\mathrm{ppb})$ & \\
\hline adventure bath & $0.36(0.18)$ & $17(10)$ & $0 / 4$ \\
adventure bath & $0.28(0.11)$ & $14(5)$ & $0 / 5$ \\
regular pool & $0.23(0.03)$ & $11(5)$ & $2 / 2$ \\
regular pool & $0.22(0.04)$ & $12(6)$ & $2 / 3$ \\
regular pool & $0.20(0.08)$ & $22(15)$ & $5 / 6$ \\
regular pool & $0.20(0.06)$ & $6(1)$ & $0 / 5$ \\
regular pool & $0.17(0.03)$ & $10(5)$ & $2 / 2$ \\
regular pool & $0.13(0.03)$ & $43(38)$ & $2 / 7$ \\
adventure bath & $0.04(0.03)$ & $17(13)$ & $13 / 39$ \\
\hline Total: $\quad(9)$ & $0.20(0.09)$ & $15(13)$ & \\
\hline
\end{tabular}


Table 2. Demographics of examined indoor swimming pool personnel subjected to nasal lavage.

\begin{tabular}{|c|c|c|c|c|c|c|}
\hline Subject & Sex & Age & Airway symptom & $\begin{array}{c}\text { Employment } \\
\text { in years }\end{array}$ & $\begin{array}{c}\text { Type of } \\
\text { employment }\end{array}$ & Facility \\
\hline 1 & $\mathrm{~F}$ & 44 & $\begin{array}{l}\text { nasal obstruction, } \\
\text { cough, dryness in } \\
\text { throat, hoarse throat }\end{array}$ & $19\left(25^{*}\right)$ & bath attendant & $\mathrm{I}$ \\
\hline 2 & $\mathrm{~F}$ & 28 & cough & 1 & $\begin{array}{l}\text { swimming instructor, } \\
\text { lifeguard }\end{array}$ & I \\
\hline 3 & $\mathrm{~F}$ & 51 & cough & 7 & reception, cleaner & II \\
\hline 4 & M & 56 & cough & $1\left(27^{*}\right)$ & swimming coach & III \\
\hline 5 & M & 41 & nasal obstruction & 3 & technician & II \\
\hline 6 & M & 50 & none & 7 & technician & $\mathrm{I}$ \\
\hline 7 & $\mathrm{~F}$ & 40 & none & 17 & bath attendant & II \\
\hline 8 & M & 51 & none & 28 & bath attendant & II \\
\hline 9 & $\mathrm{~F}$ & 26 & none & 1 & $\begin{array}{l}\text { swimming instructor, } \\
\text { lifeguard }\end{array}$ & I \\
\hline
\end{tabular}

*Total years of employment in the sector. 